\title{
BOUNDARY INVERSE PROBLEM FOR STAR-SHAPED GRAPH WITH DIFFERENT DENSITIES STRINGS-EDGES
}

\author{
A.M. Akhtyamov ${ }^{1}$, Kh.R. Mamedov ${ }^{2}$, E.N. Yilmazoglu ${ }^{2}$ \\ ${ }^{1}$ Bashkir State University, Ufa, Russian Federation \\ ${ }^{2}$ Mersin University, Mersin, Turkey \\ E-mail: AkhtyamovAM@mail.ru, hanlar@mersin.edu.tr, nur_9465@hotmail.com
}

\begin{abstract}
The paper is devoted to the mathematical modelling of star-shaped geometric graphs with $\mathrm{n}$ rib-strings of different density and the solution of the boundary inverse spectral problem for Sturm-Liouville differential operators on these graphs. Earlier it was shown that if strings have the same length and densities, then the stiffness coefficients of springs at the ends of graph strings are not uniquely recovered from natural frequencies. They are found up to permutations of their places. We show, that if the strings have different densities, then the stiffness coefficients of springs on the ends of graph strings are uniquely recovered from all natural frequencies. Counterexamples are shown that for the unique recovery of the stiffness coefficients of springs on $\mathrm{n}$ dead ends of the graph, it is not enough to use $n$ natural frequencies. Examples are also given showing that it is sufficient to use $n+1$ natural frequencies for the uniqueness of the recovery of the stiffness coefficients of springs at the $n$ ends of the strings. Those, the uniqueness or non-uniqueness of the restoration of the stiffness coefficients of springs at the ends of the strings depends on whether the string densities are identical or different.
\end{abstract}

Keywords: natural frequencies; star-shaped graph; inverse problems; strings; densities; boundary conditions.

\section{Introduction}

The main results on direct and inverse spectral problems for Sturm-Liouville operators on an interval are presented in [1-11] and other works. Differential operators on graphs (networks, trees) often appear in natural sciences and engineering (see [12-22] and the references therein). Most of the results in this direction are devoted to direct problems of studying properties of the spectrum and the root functions for operators on graphs. Inverse spectral problems, because of their nonlinearity, are more difficult to investigate, and nowadays there exists only a small number of papers in this area. In particular, inverse spectral problems of recovering the coefficients of differential operators on trees (i.e on graphs without cycles) were solved. Boundary inverse eigenvalue problems geometric graphs were considered in [23-27]. In these papers it is shown that if strings have the same length and densities, then the stiffness coefficients of springs at the ends of strings are not uniquely recovered from natural frequencies. They are found up to permutations of their places. We show, that if the strings have different densities, then the stiffness coefficients of springs on the ends of strings are uniquely recovered from natural frequencies. Those, the uniqueness or non-uniqueness of the restoration of the stiffness coefficients of springs at the ends of the strings depend on whether the string densities are identical or different. 


\section{Eigenvalues for Sturm-Liouville Differential Operators on the Star Graph}

Let $\Gamma=\gamma_{1} \times \gamma_{2} \times \cdots \times \gamma_{n}$ be a star-shaped graph which consists of $n$ finite rays $\gamma_{j}=\left\{x_{j} \in\left(0, l_{j}\right)\right\}, j=1, \ldots, n$, with the origin of each ray identified with the single vertex of the graph. We consider on $\Gamma$ the equation

$$
L y_{j}=-\frac{d^{2} y_{j}\left(x_{j}\right)}{d x_{j}^{2}}+q\left(x_{j}\right) y_{j}\left(x_{j}\right)=\rho_{j} \lambda y_{j}\left(x_{j}\right)=\rho_{j} \mu^{2} y_{j}\left(x_{j}\right), \quad x_{j} \in \gamma_{j},
$$

defined for functions $y$ satisfying the natural Kirchhoff boundary conditions on the vertex:

$$
\begin{gathered}
y_{1}(0)=\ldots=y_{n}(0), \\
y_{1}^{\prime}(0)+\ldots+y_{n}^{\prime}(0)=0 .
\end{gathered}
$$

We further require the boundary conditions on the end-points $x_{j}=l_{j}$ :

$$
y_{j}^{\prime}\left(l_{j}\right)+H_{j} y_{j}\left(l_{j}\right)=0, j=1, \cdots, n .
$$

Here $\rho_{1}, \rho_{2}, \ldots, \rho_{n}$ are different numbers, $\lambda$ and $\mu$ are spectral parameters, $H_{j} \in \mathbb{C}$. Each potential $q_{j}(x) \in L\left(\gamma_{j}\right)(j=1, \cdots, n)$.

Let $s_{j}(x, \mu), c_{j}(x, \mu), j=1, \ldots, n+1$, be the solutions of (1) on the $\gamma_{j}$ which satisfy the initial conditions $s_{j}(0, \mu)=1-c_{j}(0, \mu)=0,1-s_{j}^{\prime}(0, \mu)=c_{j}^{\prime}(0, \mu)=0(j=1, \cdots, n)$.

The general solution on every interval can be represented as

$$
y_{j}(x, \mu)=\alpha_{j}(\mu) c_{j}(x, \mu)+\beta_{j}(\mu) s_{j}(x, \mu), j=1, \cdots, n .
$$

It has to satisfy the first Kirchchoff condition (2) for the first $n$ components (5):

$$
\alpha_{1}(\mu)=\cdots=\alpha_{n}(\mu) .
$$

We denote $\alpha(\mu)=\alpha_{1}(\mu)=\cdots=\alpha_{n}(\mu)$.

Boundary conditions on the ends of finite intervals (4) put the following conditions on $\alpha(\mu), \beta_{1}(\mu), \cdots, \beta_{2}(\mu)$

$$
\alpha(\mu)\left[c_{j}^{\prime}\left(l_{j}, \mu\right)+H_{j} c_{j}\left(l_{j}, \mu\right)\right]+\beta_{j}(\mu)\left[s_{j}^{\prime}\left(l_{j}, \mu\right)+H_{j} s_{j}\left(l_{j}, \mu\right)\right]=0, j=1, \cdots, n .
$$

We define $(i=1, \cdots, n)$

$$
\begin{gathered}
\sigma_{j}(\mu)=s_{j}^{\prime}\left(l_{j}, \mu\right)+H_{j} s_{j}\left(l_{j}, \mu\right), \\
\kappa_{j}(\mu)=c_{j}^{\prime}\left(l_{j}, \mu\right)+H_{j} c_{j}\left(l_{j}, \mu\right) .
\end{gathered}
$$

Then the condition (8) can be rewritten as

$$
\alpha(\mu) \kappa_{j}(\mu)+\beta_{j}(\mu) \sigma_{j}(\mu)=0, j=1, \cdots, n .
$$

It is important to mention, that $\sigma_{j}(\mu)$ and $\kappa_{j}(\mu)$ cannot vanish simultaneously: multiply (8) by $c_{j}\left(l_{j}, \mu\right)$ and subtract $(9)$ multiplied by $s_{j}\left(l_{j}, \mu\right)$. As the result

$$
\sigma_{j}(\mu) c_{j}\left(l_{j}, \mu\right)-\kappa_{j}(\mu) s_{j}\left(l_{j}, \mu\right)=s_{j}^{\prime}\left(l_{j}, \mu\right) c_{j}\left(l_{j}, \mu\right)-c_{j}^{\prime}\left(l_{j}, \mu\right) s_{j}\left(l_{j}, \mu\right)=1 .
$$


The second Kirchhoff condition (3) requires

$$
\beta_{1}(\mu)+\cdots+\beta_{n}(\mu)=0
$$

The first series of eigenvalues. Consider the case

$$
\sigma_{1}(\mu) \cdot \sigma_{2}(\mu) \cdot \ldots \cdot \sigma_{n}(\mu) \neq 0 .
$$

Then it follows from (7) that

$$
\beta_{j}(\mu)=-\alpha(\mu) \frac{c_{j}^{\prime}\left(l_{j}, \mu\right)+H_{j} c_{j}\left(l_{j}, \mu\right)}{s_{j}^{\prime}\left(l_{j}, \mu\right)+H_{j} s_{j}\left(l_{j}, \mu\right)} .
$$

Then it follows from (12) that

$$
\alpha(\mu) \sum_{j=1}^{n} \frac{c_{j}^{\prime}\left(l_{j}, \mu\right)+H_{j} c_{j}\left(l_{j}, \mu\right)}{s_{j}^{\prime}\left(l_{j}, \mu\right)+H_{j} s_{j}\left(l_{j}, \mu\right)}=0,
$$

where $\alpha(\mu)$ is arbitrary.

If $\alpha(\mu) \equiv 0$, then $y_{j} \equiv 0$ and we don't have eigenvalues.

So eigenvalues are the roots of the equation

$$
\sum_{j=1}^{n} \frac{c_{j}^{\prime}\left(l_{j}, \mu\right)+H_{j} c_{j}\left(l_{j}, \mu\right)}{s_{j}^{\prime}\left(l_{j}, \mu\right)+H_{j} s_{j}\left(l_{j}, \mu\right)}=0 .
$$

The second series of eigenvalues. Consider the case

$$
\sigma_{1}(\mu) \cdot \sigma_{2}(\mu) \cdot \ldots \cdot \sigma_{n}(\mu)=0
$$

Denote

$$
J=\left\{j: \sigma_{j}(\mu)=0\right\} .
$$

Then $\kappa_{j}(\mu) \neq 0$, for $j \in J$, and, to fulfil the $(7)$

$$
\alpha(\mu)=0 .
$$

So the general solution in this case has to be in the form

$$
y_{j}(x, \mu)=\beta_{j}(\mu) s_{j}(x, \mu), j=1, \cdots, n .
$$

But $\sigma_{j}(\mu) \neq 0, j \notin J$, and as the result, to satisfy (7), it has to be $\beta_{j}=0$, and as the result the general solution in such case is

$$
\begin{gathered}
y_{j}(x, \mu)=\beta_{j}(\mu) s_{j}(x, \mu), j \in J, \\
y_{j}(x, \mu) \equiv 0, j \notin J,
\end{gathered}
$$

where $\beta_{j}(\mu)$ are arbitrary.

If $\beta_{j} \equiv 0(j \in J)$, then $y_{j} \equiv 0$ and we don't have eigenvalues.

So eigenvalues are the roots of the equation

$$
s_{j}(x, \mu)=0, \quad j \in J .
$$




\section{Uniqueness of Solution for Boundary Inverse Problem}

The boundary inverse problem consists of determining $H_{j}$ from eigenvalues. We note that the eigenvalues of the second series cannot be used to solve the inverse problem, since the equation for determining the eigenvalues of the second series does not contain $H_{j}$. Therefore, we assume that we know the eigenvalues from the first series.

Let $L$ denote the Sturm-Liouville eigenvalue problem $(1)-(4)$.

In that follows, the problem of type $L$ with different coefficients in the equation and with different parameters in the boundary forms is denoted by $\widetilde{L}$. Additionally, if a certain symbol denotes an object in the problem $L$, the same symbol with a tilde denotes its counterpart in problem $\widetilde{L}$.

Theorem 1. If the eigenvalues of the first series for problem $L$ are equal to those of problem $\widetilde{L}$ counting their algebraic multiplicities, then the coefficients of the boundary conditions of $L$ and $\widetilde{L}$ are also equal to each other; i.e., $H_{j}=\widetilde{H}_{j}$ for $j=1,2, \ldots n$.

Proof. If $\lambda_{i}$ are eigenvalues of the first series for problem $L$, then from (16) it follows that $\lambda_{i}$ are the roots of the entire function

$$
\Delta(\lambda)=\sum_{k=1}^{n}\left(c_{j}^{\prime}\left(l_{k}, \mu\right)+H_{k} c_{k}\left(l_{k}, \mu\right)\right) \cdot \prod_{j=1 ; j \neq k}^{n}\left(s_{j}^{\prime}\left(l_{j}, \mu\right)+H_{j} s_{j}\left(l_{j}, \mu\right)\right) .
$$

It can be seen that $\Delta(\lambda)$ is an entire function of order 1 . Moreover, according to the assumptions of the theorem, the eigenvalues of $L$ and $\widetilde{L}$ listed with their algebraic multiplicities are equal to each other. Therefore, the Hadamard factorization theorem implies that $\Delta(\lambda) \equiv C \widetilde{\Delta}(\lambda)$, where $C$ is a nonzero constant. It follows that

$$
\begin{aligned}
& \Delta(\lambda)-C \widetilde{\Delta}(\lambda) \equiv \sum_{k=1}^{n}\left(c_{k}^{\prime}\left(l_{k}, \mu\right)+H_{k} c_{k}\left(l_{k}, \mu\right)\right) \cdot \prod_{j=1 ; j \neq k}^{n}\left(s_{j}^{\prime}\left(l_{j}, \mu\right)+\widetilde{H}_{j} s_{j}\left(l_{j}, \mu\right)\right)- \\
& -C \cdot \sum_{k=1}^{n}\left(c_{k}^{\prime}\left(l_{k}, \mu\right)+\widetilde{H}_{k} c_{k}\left(l_{k}, \mu\right)\right) \cdot \prod_{j=1 ; j \neq k}^{n}\left(s_{j}^{\prime}\left(l_{j}, \mu\right)+\widetilde{H}_{j} s_{j}\left(l_{j}, \mu\right)\right) .
\end{aligned}
$$

We have the asymptotic formulas

$$
\begin{aligned}
& c_{j}\left(x_{j}, \mu\right)=\cos \left(\mu x_{j}\right)+\frac{1}{\mu} u_{j}\left(x_{j}\right) \sin \left(\mu x_{j}\right)+O\left(\frac{1}{\mu^{2}}\right), \\
& s_{j}\left(x_{j}, \mu\right)=\frac{1}{\mu} \sin \left(\mu x_{j}\right)-\frac{1}{\mu^{2}} u_{j}\left(x_{j}\right) \cos \left(\mu x_{j}\right)+O\left(\frac{1}{\mu^{3}}\right), \\
& c_{j}^{\prime}\left(x_{j}, \mu\right)=-\mu \sin \left(\mu x_{j}\right)+u_{j}\left(x_{j}\right) \cos \left(\mu x_{j}\right)+O\left(\frac{1}{\mu}\right), \\
& s_{j}^{\prime}\left(x_{j}, \mu\right)=\cos \left(\mu x_{j}\right)+\frac{1}{\mu} u_{j}\left(x_{j}\right) \sin \left(\mu x_{j}\right)+O\left(\frac{1}{\mu^{2}}\right), \quad j=1,2, \ldots, n,
\end{aligned}
$$

where $u_{j}\left(x_{j}\right)=\frac{1}{2} \int_{0}^{x} q\left(t_{j}\right) d t_{j}$ for sufficiently large $\mu \in \mathbb{R}[3]$. Hence it follows that the corresponding products of $c_{j}, s_{j}$ and their derivatives are linearly independent. From this and (25) it follows that $H_{j}=\widetilde{H}_{j}$. Thus, the theorem is proved.

The theorem shows that the boundary conditions of Problem $L$ can be uniquely recovered from the infinite set of eigenvalues. However, computer calculations show that 
enough finite number of eigenvalues is sufficient to restore $n$ parameters $H_{j}$ of $L$. In this case, for the reconstruction we need to use not $n$, but $n+1$ eigenvalues of problem $L$.

Let us demonstrate that $n$ eigenvalues are not enough for unique identification of $n$ coefficients $H_{j}$.

\section{Examples and Counterexamples}

Example 1. (Counterexample 1) Let $\Gamma=\gamma_{1} \times \gamma_{2} \times \gamma_{3}$ be a star-shaped graph which consists of 3 finite rays $\gamma_{j}=\left\{x_{j} \in(0,1)\right\}, l_{j}=1, j=1,2,3$, with the origin of each ray identified with the single vertex of the graph. We consider on $\Gamma$ equation

$$
L y_{j}=-\frac{d^{2} y_{j}\left(x_{j}\right)}{d x_{j}^{2}}=\rho_{j} \mu^{2} y_{j}\left(x_{j}\right), \quad x_{j} \in \gamma_{j},
$$

defined for functions $y$ satisfying the natural Kirchhoff boundary conditions on the vertex:

$$
\begin{gathered}
y_{1}(0)=y_{2}(0)=y_{3}(0), \\
y_{1}^{\prime}(0)+y_{2}^{\prime}(0)+y_{3}^{\prime}(0)=0 .
\end{gathered}
$$

We further require the boundary conditions on the end-points $x_{j}=l_{j}=1$ :

$$
y_{j}^{\prime}(1)+H_{j} y_{j}(1)=0, j=1, \cdots, n .
$$

Here $\mu$ is a spectral parameter, $\rho_{1}=1, \rho_{2}=2, \rho_{3}=3, H_{j} \in \mathbb{C}$.

The solutions of (26) on $\gamma_{j}$ which satisfies initial condition $s_{j}(0, \mu)=1-c_{j}(0, \mu)=0$, $1-s_{j}^{\prime}(0, \mu)=c_{j}^{\prime}(0, \mu)=0,(j=1,2,3)$ are functions $c_{j}\left(x_{j}, \mu\right)=\cos \left(\mu x_{j}\right)$ and $s_{j}\left(x_{j}, \mu\right)=$ $\frac{1}{\mu} \sin \left(\mu x_{j}\right), j=1,2,3$.

Let us take the first tree eigenvalues of the first series of eigenvalues for problem (26) - (29) $\mu_{1}=0,48450, \mu_{2}=1,4165, \mu_{3}=2,2721$. Using these values, from (16) we arrive at the system of three equations:

$$
\begin{aligned}
& \left(0,88491 H_{1}-0,22566\right)\left(0,85069 H_{2}+0,56613\right)\left(0,68327 H_{3}+0,11703\right)+ \\
& +\left(0,96133 H_{1}+0,88491\right)\left(0,56613 H_{2}-0,79876\right)\left(0,68327 H_{3}+0,11703\right)+ \\
& +\left(0,96133 H_{1}+0,88491\right)\left(0,85069 H_{2}+0,56613\right)\left(0,11703 H_{3}-1,4435\right)=0 \\
& \left(0,15372 H_{1}-1,3996\right)\left(0,10724 H_{2}-0,95274\right)\left(-0,21055 H_{3}-0,44664\right)+ \\
& +\left(0,69759 H_{1}+0,15372\right)\left(-0,95274 H_{2}-0,86063\right)\left(-0,21055 H_{3}-0,44664\right)+ \\
& +\left(0,69759 H_{1}+0,15372\right)\left(0,10724 H_{2}-0,95274\right)\left(-0,44664 H_{3}+3,8020\right)=0 \\
& \left(-0,64523 H_{1}-1,73588\right)\left(-0,21696 H_{2}-0,16736\right)\left(0,074565 H_{3}+0,86121\right)+ \\
& +\left(0,33625 H_{1}-0,64523\right)\left(-0,16736 H_{2}+4,4801\right)\left(0,074565 H_{3}+0,86120\right)+ \\
& +\left(0,33625 H_{1}-0,64523\right)\left(-0,21696 H_{2}-0,16736\right)\left(0,86120 H_{3}-3,4645\right)=0
\end{aligned}
$$

which solution will be six sets of $\left(H_{1}, H_{2}, H_{3}\right)$ :

$$
\begin{aligned}
& \left\{H_{1}=0,081922, H_{2}=3,4849, H_{3}=6,0394\right\}, \\
& \left\{H_{1}=0,31023, H_{2}=1,0390, H_{3}=31,632\right\}, \\
& \left\{H_{1}=1,0000, H_{2}=2,0000, H_{3}=3,0000\right\}, \\
& \left\{H_{1}=1,2269, H_{2}=0,90496, H_{3}=5,56392\right\}, \\
& \left\{H_{1}=-0,45154+0,17493 i, H_{2}=-3,8954+5,6196 i, H_{3}=-0,55241-2,2121 i\right\}, \\
& \left\{H 1=-0,45154-0,17493 i, H_{2}=-3,8954-5,6196 i, H_{3}=-0,55241+2,2121 i\right\} .
\end{aligned}
$$


We substitute the fourth eigenvalue $\mu_{4}=3,2689$ of the problem (26) - (29) in (16). As the result, we obtain the equation

$$
\begin{aligned}
& \left(-0,99191 H_{1}+0,41503\right)\left(0,038526 H_{2}+0,96776\right)\left(-0,038005 H_{3}-0,92795\right)+ \\
& +\left(-0,038840 H_{1}-0,99191\right)\left(0,96776 H_{2}-1,6467\right)\left(-0,038005 H_{3}-0,92795\right)+ \\
& +\left(-0,038840 H_{1}-0,99191\right)\left(0,038526 H_{2}+0,96776\right)\left(-0,92795 H_{3}+3,65503\right)=0 .
\end{aligned}
$$

Let us form a new system of equations from the first two equations of system (30) and equation (32). The solution to this new system of equations is the other 6 sets of solutions:

$$
\begin{aligned}
& \left\{H_{1}=1,4493, H_{2}=1,9584, H_{3}=2,5961\right\}, \\
& \left\{H_{1}=0,84897+1,2383 i, H_{2}=0,81210-0,30203 i, H_{3}=4,3564-1,0462 i\right\}, \\
& \left\{H_{1}=1,0000, H_{2}=2,0000, H_{3}=3,0000\right\}, \\
& \left\{H_{1}=-0,44254+0,06691 i, H_{2}=14,573+6,2654 i, H_{3}=-2,9975-1,7914 i\right\}, \\
& \left\{H_{1}=-0,44254-0,066907 i, H_{2}=14,573-6,2654 i, H_{3}=-2,9975+1,7914 i\right\}, \\
& \left\{H 1=0,84897-1,2383 i, H_{2}=0,81210+0,30203 i, H_{3}=4,3565+1,0462 i\right\} .
\end{aligned}
$$

Thus, $n$ coefficients $H_{j}$ of the boundary conditions (4) are not uniquely recovered by $n$ eigenvalues of problem $L$.

However, calculations on concrete examples show that the coefficients $H_{j}$ of the boundary conditions (4) can be uniquely determined by using $n+1$ eigenvalues of problem $L$.

Example 2. Let us take the first four eigenvalues of the first series of eigenvalues for problem (26) - (29) $\mu_{1}=0,48450, \mu_{2}=1,4165, \mu_{3}=2,2721, \mu_{4}=3,2689$. The solution of the system of four equations (30), (32) is the intersection of sets (31) and (33). This intersection consists of a unique solution of system:

$$
\left\{H_{1}=1,0000, H_{2}=2,0000, H_{3}=3,0000\right\} \text {. }
$$

Example 3. (Counterexample 2) Let $\Gamma=\gamma_{1} \times \gamma_{2} \times \gamma_{3}$ be a star-shaped graph which consists of 3 finite rays $\gamma_{j}=\left\{x_{j} \in(0,1)\right\}, j=1,2,3$, with the origin of each ray identified with the single vertex of the graph. We consider on $\Gamma$ equation

$$
L y_{j}=-\frac{d^{2} y_{j}(x)}{d x_{j}^{2}}+q_{j}(x) y_{j}(x)=\rho_{j} \mu^{2} y_{j}(x), \quad x_{j} \in \gamma_{j},
$$

defined for functions $y$ satisfying the natural Kirchhoff boundary conditions on vertex:

$$
\begin{gathered}
y_{1}(0)=y_{2}(0)=y_{3}(0), \\
y_{1}^{\prime}(0)+y_{2}^{\prime}(0)+y_{3}^{\prime}(0)=0 .
\end{gathered}
$$

We further require the boundary conditions on end-points $x_{j}=l_{j}=1$ :

$$
y_{j}^{\prime}(1)+H_{j} y_{j}(1)=0, j=1, \cdots, n
$$

Here $\mu$ is a spectral parameter, $q_{1}(x)=x, q_{2}(x)=x+2, q_{3}(x)=x+3, \rho_{1}=1, \rho_{2}=2$, $\rho_{3}=3, H_{j} \in \mathbb{C}$. 
The solutions of (35) on $\gamma_{j}$ which satisfies initial condition $s_{j}(0, \mu)=1-c_{j}(0, \mu)=0$, $1-s_{j}^{\prime}(0, \mu)=c_{j}^{\prime}(0, \mu)=0,(j=1,2,3)$ are functions that are expressed in terms of Airy functions:

$$
\begin{gathered}
c_{1}(x, \mu)=-\frac{\operatorname{Bi}\left(1,-\mu^{2}\right) \cdot \operatorname{Ai}\left(-\mu^{2}+x\right)}{\left(\operatorname{Bi}\left(-\mu^{2}\right) \cdot \operatorname{Ai}\left(1,-\mu^{2}\right)-\operatorname{Bi}\left(1,-\mu^{2}\right) \cdot \operatorname{Ai}\left(-\mu^{2}\right)\right)}+ \\
+\frac{\operatorname{Ai}\left(1,-\mu^{2}\right) \cdot \operatorname{Bi}\left(-\mu^{2}+x\right)}{\left(\operatorname{Bi}\left(-\mu^{2}\right) \cdot \operatorname{Ai}\left(1,-\mu^{2}\right)-\operatorname{Bi}\left(1,-\mu^{2}\right) \cdot \operatorname{Ai}\left(-\mu^{2}\right)\right)}, \\
c_{2}(x, \mu)=-\frac{\operatorname{Bi}\left(1,-2 \mu^{2}+2\right) \cdot \operatorname{Ai}\left(-2 \mu^{2}+x+2\right)}{\operatorname{Bi}\left(-2 \mu^{2}+2\right) \cdot \operatorname{Ai}\left(1,-2 \mu^{2}+2\right)-\operatorname{Bi}\left(1,-2 \mu^{2}+2\right) \cdot \operatorname{Ai}\left(-2 \mu^{2}+2\right)} \\
+\frac{\operatorname{Ai}\left(1,-2 \mu^{2}+2\right) \cdot \operatorname{Bi}\left(-2 \mu^{2}+x+2\right)}{\operatorname{Bi}\left(-2 \mu^{2}+2\right) \cdot \operatorname{Ai}\left(1,-2 \mu^{2}+2\right)-\operatorname{Bi}\left(1,-2 \mu^{2}+2\right) \cdot \operatorname{Ai}\left(-2 \mu^{2}+2\right)}, \\
c_{3}(x, \mu)=-\frac{\operatorname{Bi}\left(1,-3 \mu^{2}+3\right) \cdot \operatorname{Ai}\left(-3 \mu^{2}+x+3\right)}{\operatorname{Bi}\left(-3 \mu^{2}+3\right) \cdot \operatorname{Ai}\left(1,-3 \mu^{2}+3\right)-\operatorname{Bi}\left(1,-3 \mu^{2}+3\right) \cdot \operatorname{Ai}\left(-3 \mu^{2}+3\right)}
\end{gathered},
$$

Let us take the first tree eigenvalues of the first series of eigenvalues for problem (35) (38) $\mu_{1}=1,7745, \mu_{2}=2,2430, \mu_{3}=3,4376$. Using these values, from (16) we arrive at the system of three equations:

$$
\begin{aligned}
& \left(-0,12050 H_{1}-1,6315\right)\left(0,47686 H_{2}-0,31384\right)\left(0,26508 H_{3}-0,72008\right)+ \\
& +\left(0,61336 H_{1}+0,0059937\right)\left(-0,42522 H_{2}-1,8172\right)\left(0,26508 H_{3}-0,72008\right)+ \\
& +\left(0,61336 H_{1}+0,0059937\right)\left(0,47686 H_{2}-0,31384\right)\left(-0,80651 H_{3}-1,5816\right)=0, \\
& \left(-0,58101 H_{1}-1,8116\right)\left(0,13876 H_{2}-0,88951\right)\left(-0,076473 H_{3}-0,94666\right)+ \\
& +\left(0,39850 H_{1}-0,47863\right)\left(-0,95980 H_{2}-1,0540\right)\left(-0,076473 H_{3}-0,94666\right)+ \\
& +\left(0,39850 H_{1}-0,47863\right)\left(0,13876 H_{2}-0,88951\right)\left(-0,98500 H_{3}+0,88323\right)=0, \\
& \left(-0,99573 H_{1}+0,73943\right)\left(-0,21611 H_{2}-0,11628\right)\left(-0,10434 H_{3}+0,80048\right)+ \\
& +\left(-0,065638 H_{1}-0,95554\right)\left(-0,11388 H_{2}+4,5660\right)\left(-0,10434 H_{3}+0,80048\right)+ \\
& +\left(-0,065638 H_{1}-0,95554\right)\left(-0,21611 H_{2}-0,11628\right)\left(0,81475 H_{3}+3,3335\right)=0,
\end{aligned}
$$


which solution will be six sets of $\left(H_{1}, H_{2}, H_{3}\right)$ :

$$
\begin{aligned}
& \left\{H_{1}=3,0000, H_{2}=2,0000, H_{3}=1,0000\right\}, \\
& \left\{H_{1}=3,3145, H_{2}=0,29642, H_{3}=4,6856\right\}, \\
& \left\{H_{1}=0,80324+6,5631 i, H_{2}=0,86403-1,4760 i, H_{3}=0,33506+1,3100 i\right\}, \\
& \left\{H_{1}=-0,81785+0,49296 i, H_{2}=-0,42624+4,92103 i, H_{3}=-0,12302-4,2522 i\right\}, \\
& \left\{H_{1}=-0,81785-0,49295 i, H_{2}=-0,42624-4,9210 i, H_{3}=-0,12302+4,2522 i\right\}, \\
& \left\{H 1=0,80324-6,5631 i, H_{2}=0,86403+1,4760 i, H_{3}=0,33506-1,3100 i\right\} .
\end{aligned}
$$

We substitute the fourth eigenvalue $\mu_{4}=4,9887$ of problem (35) - (38) in (16). As the result, we obtain equation

$$
\begin{aligned}
& \left(0,22829 H_{1}+4,8126\right)\left(0,081214 H_{2}+0,82564\right)\left(0,099045 H_{3}-0,54720\right)+ \\
& +\left(-0,19737 H_{1}+0,21965\right)\left(0,83356 H_{2}-3,8390\right)\left(0,099045 H_{3}-0,54720\right)+ \\
& +\left(-0,19737 H_{1}+0,21965\right)\left(0,081213 H_{2}+0,82564\right)\left(-0,55175 H_{3}-7,0481\right)=0 .
\end{aligned}
$$

Let us form the new system of equations from the first two equations of system (39) and equation (41). The solution to this new system of equations is the other 6 sets of solutions:

$$
\begin{aligned}
& \left\{H_{1}=3,0000, H_{2}=2,0000, H_{3}=1,0000\right\}, \\
& \left\{H_{1}=1,5805+2,4752 i, H_{2}=-0,22203+0,67498 i, H_{3}=1,0034-3,6902 i\right\}, \\
& \left\{H_{1}=-0,059508+0,67472 i, H_{2}=-6,1889-6,1889 i, H_{3}=0,93238-2,1799 i\right\}, \\
& \left\{H_{1}=-0,46343, H_{2}=54,238, H_{3}=11,361\right\}, \\
& \left\{H_{1}=-0,059508-0,67473 i, H_{2}=-6,1889+0,090512 i, H_{3}=0,93238+2,1799 i\right\}, \\
& \left\{H 1=1,5804-2,4751 i, H_{2}=-6,1889+0,090512 i, H_{3}=1,0034+3,6901 i\right\} .
\end{aligned}
$$

Thus, both systems do not have a unique solution.

Example 4. Let us take the first four eigenvalues of problem (35) - (38) $\mu_{1}=1,7745$, $\mu_{2}=2,2430, \mu_{3}=3,4376, \mu_{4}=4,9887$. The solution of the system of four equations (39), (41) is the intersection of sets (40) and (42). This intersection consists of a unique solution:

$$
\left\{H_{1}=3,0000, H_{2}=2,0000, H_{3}=1,0000\right\} .
$$

We note that in the case of an arbitrary infinitely differentiable functions $q_{j}\left(x_{j}\right)$, in calculating the characteristic determinant (24), instead of the exact values of the linearly independent solutions $c_{j}(x, \mu)$ and $s_{j}(x, \mu)$ of equation (1), the main parts of the Taylor series for these solutions are used with respect to the two variables $x$ and $\mu$. Moreover, the coefficients of the boundary conditions (for the inverse problem) and the eigenvalues (for the direct problem) are found with a small error, and the accuracy of the calculation is sufficiently high [28].

Acknowledgements. The reported research was funded by Russian Foundation for Basic Research, the government of the region of the Republic of Bashkortostan (projects 1851-06002-Az_a 18-01-00250_a, 17-41-020230-r_a), and the Science Development Fund under the President of the Republic of Azerbaijan (project on the 1st Azerbaijan-Russian International Grant Competition (EIF-BGM-4-RFTF-1/2017)). 


\section{References}

1. Levitan B.M. Inverse Sturm-Liouville Problems. Utrecht, VNU Science Press, 1987. DOI: $10.1515 / 9783110941937$

2. Marchenko V.A. Sturm-Liouville Operators and Applications. Basel, Boston, Stuttgart, Birkhauser, 1986. DOI: 10.1007/978-3-0348-5485-6

3. Naimark M.A. Linear Differential Operators. Part II. Linear Differential Operators in Hilbert Space. London, Toronto, Sydney, Frederick Ungar Publishing, 1968.

4. Levitan B.M., Gasymov M.G. Determination of a Differential Equation by Two of Its Spectra. Russian Mathematical Surveys, 1964, vol. 19, no. 2, pp. 1-63. DOI: $10.1070 / R M 1964 \mathrm{v} 019 \mathrm{n} 02 \mathrm{ABEH} 001145$

5. Gasymov M.G., Guseinov I.M., Nabiev I.M. The Inverse Problem for the Sturm-Liouville Operator with Non-Separable Self-Adjoint Boundary Conditions. Sibirskii Matematicheskii Journal, 1991, vol. 31, no. 6, pp. 46-54. (in Russian)

6. Panakhov E.S., Koyunbakan H., Unal Ic. Reconstruction Formula for the Potential Function of Sturm-Liouville Problem with Eigenparameter Boundary Condition. Inverse Problems in Science and Engineering, 2010, vol. 18, no. 1, pp. 173-180. DOI: 10.1080/17415970903234976

7. Mamedov Kh.R, Cetinkaya F.A. A Uniqueness Theorem for a Sturm-Liouville Equation with Spectral Parameter in Boundary Conditions. Applied Mathematics and Information Sciences, 2015, vol. 9, no. 2, pp. 981-988.

8. Sadovnichii V.A., Sultanaev Ya.T., Akhtyamov A.M. General Inverse Sturm-Liouville Problem with Symmetric Potential. Azerbaijan Journal of Mathematics, 2015, vol. 5, no. 2, pp. 96-108.

9. Akhtyamov A.M., Sadovnichy V.A., Sultanaev Ya.T. Inverse Problem for the Diffusion Operator with Symmetric Functions and General Boundary Conditions. Eurasian Mathematical Journal, 2017, vol. 8, no. 1, pp. 10-22.

10. Kadchenko S.I. A Numerical Method for Solving Inverse Problems Generated by the Perturbed Self-Adjoint Operators. Bulletin of the South Ural State University. Series: Mathematical Modelling, Programming and Computer Software, 2013, vol. 6, no. 4, pp. 15-25.

11. Kadchenko S.I., Zakirova G.A. A Numerical Method for Inverse Spectral Problems. Bulletin of the South Ural State University. Series: Mathematical Modelling, Programming and Computer Software, 2015, vol. 8, no. 3, pp. 116-126. DOI: 10.14529/mmp150307

12. Pokornyi Yu.V., Penkin O.V., Pryadiev V.L., Borvskih A.V., Lazarev K.P., Shabrov S.A. Differential Equations on Geometric Graphs. Moscow, Fizmatlit, 2005. (in Russian)

13. Faddeev M.D., Pavlov B.S. Model of Free Electrons and the Scattering Problem. Theoretical and Mathematical Physics, 1983, vol. 55, no. 2, pp. 485-492. DOI: 10.1007/BF01015809

14. Kottos T., Smilansky U. Quantum Chaos on Graphs. Physical Review Letters, 1997, vol. 79, pp. 4794-4797. DOI: 10.1103/PhysRevLett.79.4794

15. Langese J.E., Leugering G., Schmidt J.P. Modelling, Analysis and Control of Dynamic Elastic Multi-Link Structures. Boston, Birkhäuser, 1994.

16. Pokornyi Yu.V., Borovskikh A.V. Differential Equations on Networks (Geometric Graphs). Journal of Mathematical Sciences, 2004, vol. 119, no. 6, pp. 691-718. DOI: 10.1023/B:JOTH.0000012752.77290.fa

17. Pokornyi Yu.V., Pryadiev V. The Qualitative Sturm-Liouville Theory on Spatial Networks. Journal of Mathematical Sciences, 2004, vol. 119, no. 6, pp. 788-835. DOI: 10.1023 B:JOTH.0000012756.25200.56 
18. Sobolev A., Solomyak M. Schrödinger Operator on Homogeneous Metric Trees: Spectrum in Gaps. Reviews in Mathematical Physics, 2002, vol. 14, no. 5, pp. 421-467. DOI: $10.1142 /$ S0129055X02001235

19. Belishev M.I. Boundary Spectral Inverse Problem on a Class of Graphs (Trees) by the BC Method. Inverse Problems, 2004, vol. 20, pp. 647-672. DOI: 10.1088/0266-5611/20/3/002

20. Brown B.M., Weikard R. A Borg-Levinson Theorem for Trees. Proceedings of The Royal Society. A Mathematical Physical and Engineering Sciences, 2005, vol. 464, no. 2062, pp. 3231-3243. DOI: $10.1098 /$ rspa.2005.1513

21. Sviridyuk G.A., Shipilov A.S. Stability of Solutions of Linear Oskolkov Equations on a Geometric Graph. Bulletin of the Samara State Technical University. Series: Physical and Mathematical Sciences, 2009, vol. 19, no. 2, pp. 9-16. (in Russian)

22. Sviridyuk G.A., Zagrebina S.A., Pivovarova P.O. Hoff Equation Stability on a Graph. Bulletin of the Samara State Technical University. Series: Physical and Mathematical Sciences, 2010, vol. 20, no 1, pp. 6-15. (in Russian)

23. Akhtyamov A.M., Theory of Identification of Boundary Conditions and Its Applications. Moscow, Fizmatlit, 2009. (in Russian)

24. Sadovnichii V.A., Sultanaev Ya.T., Valeev N.F. Multiparameter Inverse Spectral Problems and Their Applications. Doklady Mathematics, 2009, vol. 79, no. 3, pp. 390-393. DOI: $10.1134 /$ S1064562409030247

25. Martynova Yu.V. A Model Inverse Spectral Problem for the Sturm-Liouville Operator on a Geometric Graph. Bulletin of Bashkir University, 2011, vol. 16, no. 1, pp. 4-10. (in Russian)

26. Akhtyamov A.M., Aksenova Z.F. Identification of Parameters of Elastic Fastening of a Mechanical System from Strings. Modern problems of science and education, 2015, no. 1, available at: www.science-education.com/121-18706. (in Russian)

27. Kadchenko S.I., Kakushkin S.N., Zakirova G.A. Spectral Problems on Compact Graphs. Bulletin of the South Ural State University. Series: Mathematical Modelling, Programming and Computer Software, 2017, vol. 10, no. 3, pp. 156-162. DOI: 10.14529/mmp170314

28. Akhtyamov A.M., Utyashev I.M. Identification of Boundary Conditions at Both Ends of a String from the Natural Vibration Frequencies. Acoustical Physics, 2015, vol. 61, no. 6, pp. 615-622. DOI: $10.1134 /$ S1063771015050012

Received July 4, 2018

УДК 517.984 .54

DOI: $10.14529 / \mathbf{m m p} 180301$

\section{ГРАНИЧНАЯ ОБРАТНАЯ ЗАДАЧА ДЛЯ ЗВЕЗДООБРАЗНОГО ГРАФА СО СТРУНАМИ-РЕБРАМИ РАЗЛИЧНОЙ ПЛОТНОСТИ}

\section{А.М. Ахтямов ${ }^{1}$, Х.Р. Мамедов ${ }^{2}$, Э.Н. Йылмазоглу ${ }^{2}$}

${ }^{1}$ Башкирский государственный университет, г. Уфа, Российская Федерация

${ }^{2}$ Мерсинский университет, г. Мерсин, Турция

Работа посвящена математическому моделированию звездообразных геометрических графов с $n$ струнами-ребрами различной плотности и решению граничной обратной спектральной задачи для дифференциальных операторов Штурма - Лиувилля 
на этих графах. Ранее было показано, что, если струны имеют одинаковую длину и плотность, то коэффициенты жесткости пружин на концах струн восстанавливаются по собственным частотам неоднозначно. Они находятся с точностью до перестановок их местами. В настоящей статье показано, что, если струны имеют разную плотность, то коэффициенты жесткости пружин на концах струн восстанавливаются по всем собственным частотам однозначно. Приведены контрпримеры, показывающие, что для однозначного восстановления коэффициентов жесткостей пружинок на $n$ тупиковых вершинах графа недостаточно использования n собственных частот. Приводятся также примеры, показывающие, что для однозначного восстановления коэффициентов жесткостей пружин на $n$ концах струн достаточно использовать $n+1$ собственную частоту. Таким образом, однозначность или неоднозначность восстановления коэффициентов жесткостей пружин на концах струн зависят от того, являются ли плотности струн одинаковыми или различными.

Ключевые слова: собственные частоты; звезднообразный граф; обратные задачи; струны; плотности; краевые условия.

\section{Литература}

1. Levitan, B.M. Inverse Sturm - Liouville problems / B.M. Levitan. - Utrecht: VNU Science Press, 1987.

2. Marchenko, V.A. Sturm - Liouville Operators and Applications / V.A. Marchenko. - Basel; Boston; Stuttgart: Birkhauser, 1986.

3. Naimark, M.A. Linear Differential Operators. Part II. Linear Differential Operators in Hilbert Space / M.A. Naimark. - London, Toronto, Wellington, Sydney: Frederick Ungar Publishing, 1968 .

4. Levitan, B.M. Determination of a Differential Equation by Two of Its Spectra / B.M. Levitan, M.G. Gasymov // Russian Mathematical Surveys. - 1964. - V. 19, № 2. - P. 1-63.

5. Гасымов, М.Г. Обратная задача для оператора Штурма - Лиувилля с неразделенными самосопряженными граничными условиями / М.Г. Гасымов, И.М. Гусейнов, И.М. Набиев // Сибирский математический журнал. - 1991. - Т. 31, № 6. - С. 46-54.

6. Panakhov, E.S. Reconstruction Formula for the Potential Function of Sturm - Liouville Problem with Eigenparameter Boundary Condition / E.S. Panakhov, H. Koyunbakan, Ic. Unal // Inverse Problems in Science and Engineering. - 2010. - V. 18, № 1. - P. 173-180.

7. Mamedov, Kh.R. A Uniqueness Theorem for a Sturm - Liouville Equation with Spectral Parameter in Boundary Conditions / Kh.R. Mamedov, F.A. Cetinkaya // Applied Mathematics and Information Sciences. - 2015. - V. 9, № 2. - P. 981-988.

8. Sadovnichii, V.A. General Inverse Sturm - Liouville Problem with Symmetric Potential / V.A. Sadovnichii, Ya.T. Sultanaev, A.M. Akhtyamov // Azerbaijan Journal of Mathematics. 2015. - V. 5, № 2. - P. 96-108.

9. Akhtyamov, A.M. Inverse Problem for the Diffusion Operator with Symmetric Functions and General Boundary Conditions / A.M. Akhtyamov, V.A. Sadovnichii, Ya.T. Sultanaev // Eurasian Mathematical Journal. - 2017. - V. 8, № 1. - P. 10-22.

10. Kadchenko, S.I. A Numerical Method for Solving Inverse Problems Generated by the Perturbed Self-Adjoint Operators / S.I. Kadchenko // Вестник ЮУрГУ. Серия: Математическое моделирование и программирование. - 2013. - Т. 6, № 4. - С. 15-25.

11. Kadchenko, S.I. A Numerical Method for Inverse Spectral Problems / S.I. Kadchenko, G.A. Zakirova // Вестник ЮУрГУ. Серия: Математическое моделирование и программирование. - 2015. - Т. 8, № 3. - С. 116-126. 
12. Покорный, Ю.В. Дифференциальные уравнения на графах / Ю.В. Покорный, О.В. Пенкин, В.Л. Прядиев, А.В. Боровских, К.П. Лазарев, С.А. Шабров. - М.: Физмалит, 2005.

13. Faddeev, M.D. Model of Free Electrons and the Scattering Problem / M.D. Faddeev, B.S. Pavlov // Theoretical and Mathematical Physics. - 1983. - V. 55, № 2. - P. 485-492.

14. Kottos, T. Quantum Chaos on Graphs / T. Kottos, U. Smilansky // Physical Review Letters. - 1997. - V. 79. - P. 4794-4797.

15. Langese, J.E. Modelling, Analysis and Control of Dynamic Elastic Multi-Link Structures / J.E. Langese, G. Leugering, J.P. Schmidt. - Boston: Birkhäuser, 1994.

16. Pokornyi, Yu.V. Differential Equations on Networks (Geometric Graphs) / Yu.V. Pokornyi, A.V. Borovskikh // Journal of Mathematical Sciences. - 2004. - V. 119, № 6. - P. 691-718.

17. Pokornyi, Yu.V. The Qualitative Sturm - Liouville Theory on Spatial Networks / Yu.V. Pokornyi, V. Pryadiev // Journal of Mathematical Sciences. - 2004. - V. 119, № 6. P. 788-835.

18. Sobolev, A. Schrödinger Operator on Homogeneous Metric Trees: Spectrum in Gaps A. Sobolev, M. Solomyak // Reviews in Mathematical Physics. - 2002. - V. 14, № 5. P. $421-467$.

19. Belishev, M.I. Boundary Spectral Inverse Problem on a Class of Graphs (Trees) by the BC Method / M.I. Belishev // Inverse Problems. - 2004. - V. 20. - P. 647-672.

20. Brown, B.M. A Borg - Levinson Theorem for Trees / B.M. Brown, R. Weikard // Proceedings of the Royal Society. A Mathematical Physical and Engineering Sciences. - 2005. - V. 464, № 2062. - P. 3231-3243.

21. Свиридюк, Г.А. Устойчивость решений линейных уравнений Осколкова на геометрическом графе / Г.А. Свиридюк, А.С. Шипилов // Вестник Самарского государственного технического университета. Серия: Физико-математические науки. - 2009. - Т. 19, № 2. C. $9-16$.

22. Свиридюк, Г.А., Устойчивость уравнения Хоффа на графе / Г.А. Свиридюк, С.А. Загребина, П.О. Пивоварова // Вестник Самарского государственного технического университета. Серия: Физико-математические науки. - 2010. - Т. 20, № 1. - С. 6-15.

23. Ахтямов, А.М. Теория идентификации граничных условий и ее приложений / A.M. Axтямов. - М.: Физмалит, 2009.

24. Sadovnichii, V.A. Multiparameter Inverse Spectral Problems and Their Applications / V.A. Sadovnichii, Ya.T. Sultanaev, N.F. Valeev // Doklady Mathematics. - 2009. - V. 79, № 3. - P. 390-393.

25. Мартынова, Ю.В. Модель обратной обратной спектральной задачи для оператора Штурма - Лиувилля на геометрическом графе / Мартынова Ю.В. // Вестник Башкирского университета. - 2011. - Т. 16, № 1. - С. 4-10.

26. Ахтямов, А.М., Идентификация параметров упругого крепления механической системы от струн / А.М. Ахтямов, З.Ф. Аксенова // Современные проблемы науки и образования. - 2015. - № 1. - URL: www.science-education.com/121-18706.

27. Kadchenko, S.I. Spectral Problems on Compact Graphs / S.I. Kadchenko, S.N. Kakushkin, G.A. Zakirova // Вестник ЮУрГУ. Серия: Математическое моделирование и программирование. - 2017. - Т. 10, № 3. - С. 156-162.

28. Akhtyamov, A.M. Identification of Boundary Conditions at Both Ends of a String from the Natural Vibration Frequencies / A.M. Akhtyamov, I.M. Utyashev // Acoustical Physics. 2015. - V. 61, № 6. - P. 615-622. 
Работа проводилась при финансовой поддержке РФФИ и Правительства Республики Башкортостан (проекты 18-51-06002-Аз_а, 18-01-00250-а, 17-41-020230p_a), а также Фонда развития науки при Президенте Азербайджанской Республики (проект 1-го Азербайджанско-Российского международного конкурса грантов (EIF-BGM-4-RFTF-1/2017)).

Азамат Мухтарович Ахтямов, доктор физико-математических наук, профессор, кафедра математического моделирования, Башкирский государственный университет (г. Уфа, Российская Федерация), AkhtyamovAM@mail.ru.

Ханлар Рашидоглу Мамедов, доктор физико-математических наук, профессор, руководитель департамента математики, Мерсинский университет (г. Мерсин, Турция), hanlar@mersin.edu.tr.

Эмине Нур Йылмазоглу, докторант, Мерсинский университет (г. Мерсин, Турция), nur_9465@hotmail.com.

Поступила в редакиию 4 июля 2018 г. 